SATHER CLASSICAL LECTURES

Volume Twenty-eight

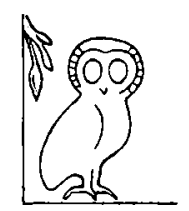

\title{
REPRESENTATIVE GOVERNMENT
}

in Greek and Roman History 



\title{
REPRESENTATIVE
}

\section{GOVERNMENT}

IN GREEK AND

\section{ROMAN HISTORY}

\author{
J. A. O. LARSEN
}

UNIVERSITY OF CALIFORNIA PRESS BERKELEY AND LOS ANGELES 1955 
University of California Press

Berkeley and Los Angeles, California

Cambridge University Press

London, England

Copyright, 1955, by

The Regents of the University of California

Library of Congress Catalogue Card No. 55-6998

Printed in the United States of America By the University of California Printing Department 